\title{
Social Media and its Value to Local Restaurants in Egypt
}

Fatma M. Abdel-aal HanyEssam El-din Mohamed

Faculty of Tourism and Hotel Management,

Helwan University Helwan University

\begin{abstract}
The social media has become the most important tool for marketing. However, measuring the effect of using social media pages on local restaurants' productivity and benefits is still lacking in Egypt. Eighteen local restaurants located in Cairo, Alexandria and Mansoura were used to identify opinions of restaurant owners or managers about measuring the effectiveness of using social media pages on their restaurants' performance, along with a customer questionnaire to explore to what extent they used social media to choose their local restaurants. The results showed that social media pages are becoming one of the most important marketing tools in local restaurants; and cheaper than traditional marketing tools. As a result, it is very important for restaurant managers to focus on social media pages to establish successful relationships with their customers.
\end{abstract}

Keywords: Social media, marketing tools, local restaurants.

\section{Literature Review}

\section{Overview of Social Media}

Social media marketing and traditional marketing are two diverse ways of marketing which need to be understood for successful marketing. In social media marketing, finding new customers through recommendation of potential and loyal customers are considered as important platform i.e. word-of-mouth. Word-of-mouth plays a vital role in social media marketing as social media is a free platform which has two-way communication with customers. On the other hand, traditional marketing is one way communication (Timilsina, 2017).

Social media creates a platform that permits customers instantly to report satisfaction or dissatisfaction about services or products. Thus, a restaurant can understand areas that progressed or need improvements. Nevertheless, at the same time, a restaurant should note that managing consumers' feedback in social media is significant and it can even damage a business when it is not well-managed (Gelb and Sundaram, 2002). Consumers share experiences through social media and propose ideas to others while developing new relationships within their communities. Hence, many hospitality firms regard social media as a powerful tool to boost consumer loyalty and satisfaction (Kasavana, 2008). Therefore, social channels help to amplify charisma, profits and collect followers. Examples of social media websites include Twitter and facebook. (Walter, 2012).

Social media is an amalgamation of application over the internet that aids consumers and prospective consumers to share opinions, knowledge about products and their experiences with each other (Kaplan and Haenlein, 2009). Social media has become a significant force in consumer decision making, including such areas as increasing awareness, sharing information, forming opinions and attitudes, purchasing, and evaluating post purchase experience (Mangold and Faulds, 2009).

Many customers believe that through social media, they can share their opinions and views with many people in a very short time, and this indicates that consumers are recently more used to smoothly get the news and faster instead of searching for information (Severi et al., 2014). The term "Social network" is defined as "A network of social interactions and personal relationship" (Oxford dictionaries. com, 2015).

\section{Social Media in the Hospitality Industry}

One of the crucial elements of e-business and e-commerce management is customer relation management because it detects the best customers and keeps their relationship with the organization. While the new intermediaries thanks to online technology, the e-CRM coordinates communication between old costumers, new ones and the company through the online technologies (Kennedy, 2006). Social media channels are effective regarding cost. They are also a useful way to get necessary information on consumer-to-consumer connection (Brodie et al., 2009). Moreover, Brooks (2009) mentioned that social media builds online relationships through user-generated contents and by adding value to products and services. Social media applications have become targeted and cost-efficient marketing tools that restaurants use in order to identify and analyze customers' perception. So, restaurants use customers' feedback to transform information into data by using targeting engines so as to increase effective communications and develop the products and services according to customers' needs and desires. Mangold and Faulds (2009) added that social media permits the institution to communicate with existing and potential customers and stimulate a sense of community on the progress of the projects. Additionally, the rich information available on the site can help entrepreneurs to improve relationships with customers. Social media can be a perfect method to obtain new customers and maintain existence. The real challenge lurks in the way of dealing with the audience at the personal level. Many business reports also revealed that restaurant entrepreneurs can attract business and raise sales with Twitter and Facebook (Maines, 2009; Young, 2010). Therefore, Needles and Thompson, (2013) summarized in their research the weighted average of the most reasons for using social media in hospitality industry as follows:

- Increase of brand awareness $(23 \%)$

- Increase of loyalty (21)

- $\quad$ Bringing in new customers $(21 \%)$

- Increase of customer connection to brand (19\%), and

- Increase of revenues $(16 \%)$.

Brodie et al. (2009) stated that social media enables restaurants to communicate with loyal customers and develops the customers' perceptions of the offered product or services, then share information and learn more about the customers. Moreover, Bulearca and Bulearca (2010) added that many customers believe that social media allows them to share their opinions and perspectives with many people in a very short time, and this means that consumers can recently get the news in easier and faster ways instead of searching for information. Therefore, customers think that social media have become a basic part of their lives. The multidirectional online 
communication has been created to keep hardware development of electronic devices. Additionally, all these devices that have access to the internet permit creation of metadata. (Wyrwoll, 2014). Social media is one of the internet based programs that targets enabling consumers to share their own points of view, information, and past experiences through the sites (Hanaysha.2016). Needles and Thompson (2013) stated that particularly for small business operators in the restaurant industry, social media offers low-cost advertising to raise market share and enhance restaurant sales. In addition, Kucukemiroglu and Kara, (2015) assured that Facebook is the most dominant social network. Therefore, entrepreneurs in small industries like restaurant will understand the techniques to affect their brands and services through eWOM (electronic word of mouth) communication process. Features such as participation, social connection, innovativeness and experiences are the chief factors which tend to spread eWOM in social networks. An organization can be ideal in competitive business environment because of successful examination of customer's involvement in eWOM

According to Soewandi (2015), social media developed as a new mechanism for restaurants to deal with its customers. Social media in business has several effects such as increasing exposure, increasing traffic, generating loyal fans and creating business intelligence. Consequently, marketers want to know their product quality and capability through social media. Finally, improving sales and reduced expenses in marketing are the most significant benefits of social media marketing (Barker et al., 2016). Social media is a dominating tool of all brand types for ultimate sales. Upgrading business plans and making changes admitting the desire of loyal customers can be carried out via utilizing feedbacks received from social sites. However, organizations do not always receive positive feedbacks. Negative comments in social site hamper both business and image (Billingsley, 2017).

\section{Methodology}

The aim of this study is to measure the effect of using social media and its value to local restaurants in Egypt. The study sample was random and included 18 restaurants in Cairo, Mansoura, and Alexandria; six restaurants in each city. A semi-structured questionnaire was developed and given to 180 customers; 10 forms in each restaurant resulting in 137 completed forms with a response rate of $76 \%$. Interviews were conducted with eighteen restaurant managers or owners in local restaurants. The Kruskal-Wallis H test was used to compare the customer's perception among the three regions (Cairo, Alexandria and Mansoura) regarding ten issues related to social media.

\section{Results and Discussion \\ Questionnaire Results \\ Question one: The most attractive source to visit a new local restaurant}

Table (1): The most attractive source to visit a new local restaurant

\begin{tabular}{|l|c|c|c|c|c|c|c|}
\hline Attractive source & freq & $\%$ & Restaurant & $\begin{array}{c}\text { Mean Rank } \\
\text { Score }\end{array}$ & $\begin{array}{c}\text { Std. } \\
\text { Deviation }\end{array}$ & $\begin{array}{c}\text { Chi- } \\
\text { Square }\end{array}$ & $\begin{array}{c}\text { Asymp. Sig. } \\
\text { (2-tailed) }\end{array}$ \\
\hline $\begin{array}{l}\text { Ask friends or } \\
\text { relatives }\end{array}$ & 36 & 26.3 & Cairo & 70.44 & 1.265 & 2.428 & .297 \\
\cline { 1 - 4 } $\begin{array}{l}\text { Newspapers and } \\
\text { Magazines }\end{array}$ & 11 & 8.0 & Alexandria & 74.75 & & & \\
\cline { 1 - 3 } $\begin{array}{l}\text { Contact directly } \\
\text { with the restaurant }\end{array}$ & 25 & 18.2 & Mansoura & 62.41 & & \\
\cline { 1 - 5 } Using social media & 65 & 47.4 & & & & \\
\hline
\end{tabular}

The findings (Table 1) indicate using social media to get more information about new local restaurants with an average percent of $(47.4 \%)$, while the recommendations of friends or relatives represent the second source used by the respondents for choosing new local restaurants $(26.3 \%)$, followed by newspapers and magazines were $(8 \%)$, while $(18.2 \%)$ of the respondents prefer to contact directly with local restaurants. The results also illustrate that the customers in Alexandria use social media sites more than those in other regions with a higher mean rank score $\mathrm{M}=(74.75)$.

\section{Question two: The most popular social media tool used by the respondents}

Table (2): The most popular social media tool used by the respondents

\begin{tabular}{|c|c|c|c|c|c|c|c|}
\hline & \\
\hline Most Popular & freq & $\%$ & $\begin{array}{l}\text { Restaurant } \\
\text { Region }\end{array}$ & $\begin{array}{l}\text { Mean Rank } \\
\text { Score }\end{array}$ & $\begin{array}{c}\text { Std. } \\
\text { Deviation }\end{array}$ & Chi-Square & $\begin{array}{c}\text { Asymp. Sig } \\
\text { (2-tailed) }\end{array}$ \\
\hline Facebook & 83 & 60.6 & Cairo & 71.68 & \multirow[t]{5}{*}{1.02852} & \multirow[t]{5}{*}{3.373} & \multirow[t]{5}{*}{.185} \\
\hline Instgram & 30 & 21.9 & Alexandria & 59.43 & & & \\
\hline Whatapp & 12 & 8.8 & \multirow[t]{3}{*}{ Mansoura } & \multirow[t]{3}{*}{73.87} & & & \\
\hline Twitter & 9 & 6.6 & & & & & \\
\hline Others & 3 & 2.2 & & & & & \\
\hline
\end{tabular}

The results (Table 2) show that Facebook was the most popular and usable tool used by the respondents in the three investigated regions with an average $(60.6 \%)$. In the second place came instagram $(21.9 \%)$, then whatsapp $(8.8 \%)$. On the other hand, other social media tools were less usable sources used by the respondents $(2.2 \%)$. These results indicate that Facebook has become the most popular social media tool used nowadays regardless the region selected. There are no significant differences $(\mathrm{P}<0.05)$ amongrestaurants' regions in terms of this issue. These results confirm the previous findings mentioned by Windels (2012) who mentioned that the restaurant operators and customers prefer Facebook. 
Question three: How many times the respondents post, like or share their comments on a restaurant account or page

Table (3): How many times the respondents post, like or share their comments on a restaurant's account

\begin{tabular}{|c|c|c|c|c|c|c|c|}
\hline $\begin{array}{c}\text { How many } \\
\text { times }\end{array}$ & freq & $\%$ & $\begin{array}{c}\text { or } \\
\begin{array}{c}\text { Restaurant } \\
\text { Region }\end{array}\end{array}$ & $\begin{array}{l}\text { ge } \\
\text { Mean } \\
\text { Rank } \\
\text { Score }\end{array}$ & $\begin{array}{c}\text { Std. } \\
\text { Deviation }\end{array}$ & $\begin{array}{c}\text { Chi- } \\
\text { Square }\end{array}$ & $\begin{array}{l}\text { Asymp. } \\
\text { Sig. (2- } \\
\text { tailed) }\end{array}$ \\
\hline $\begin{array}{l}\text { Once per } \\
\text { week }\end{array}$ & 37 & 27.0 & Cairo & 62.88 & \multirow[t]{4}{*}{.85549} & \multirow[t]{4}{*}{5.613} & \multirow[t]{4}{*}{.060} \\
\hline $\begin{array}{l}\text { Once per } \\
\text { month }\end{array}$ & 64 & 46.7 & Alexandria & 80.87 & & & \\
\hline Rarely & 27 & 19.7 & \multirow[t]{2}{*}{ Mansoura } & \multirow[t]{2}{*}{66.32} & & & \\
\hline Never ever & 9 & 6.6 & & & & & \\
\hline
\end{tabular}

The findings (Table 3$)$ indicate that $(46.7 \%)$ of the respondents post, like or share their comments on a restaurant's account or page one time per month. Moreover, few numbers $(6.6 \%)$ of them didn't post, share or like their opinions ever. Furthermore, $(27 \%)$ post their comment on a restaurant's account once per week. This result confirms that most of the restaurants' customers are less likely to share restaurants news regularly. Also the results show that Alexandria respondents were the most users with a higher score $(80.87 \%)$. It can be noticed that the Kruskal-Wallis H test revealed no significant difference among restaurants' regions regarding this issue. These findings consent with Akhundzada (2016) who indicated that customers less likely react to posts, comments, or share pictures.

Question four: Customers' answers regarding checking the restaurants' pages of social media before visiting a new restaurant.

Table (4): Customers' answers regarding checking the restaurants' pages of social media before visiting a new restaurant

\begin{tabular}{|c|c|c|c|c|c|c|c|}
\hline $\begin{array}{c}\text { checking } \\
\text { restaurants } \\
\text { 'pages }\end{array}$ & Freq & $\%$ & $\begin{array}{c}\text { Restaurant } \\
\text { Region }\end{array}$ & $\begin{array}{c}\text { Mean } \\
\text { Rank } \\
\text { Score }\end{array}$ & Deviation & $\begin{array}{c}\text { Chi- } \\
\text { Square }\end{array}$ & $\begin{array}{c}\text { Asymp. } \\
\text { Sig. } \\
\text { tailed) }\end{array}$ \\
\hline Yes & 96 & 70.1 & Cairo & 67.53 & .45962 & 5.720 & .057 \\
\hline No & 41 & 29.9 & Alexandria & 61.12 & & \\
\cline { 4 - 5 } & & Mansoura & 77.42 & & \\
\end{tabular}

The results of Table 4 show that the majority (70.1\%) of the respondents check restaurants' pages on social media before visiting a restaurant for a new time, while approximately $(29.9 \%)$ of them do not check the restaurant pages. Furthermore, the results state that Mansoura respondents were the most to check their restaurants' pages before visiting with a mean rank score of $(77.42 \%)$, while Alexandria was the least region whose respondents check restaurants' pages on social media with a mean rank score of $(61.12 \%)$, in between comes Cairo with a mean rank score of 67.53. The results also show no significant differences $(\mathrm{P}<0.05)$ among them. These findings confirm those of Akhundzada (2016) who indicated that customers like to read and check the social media profiles of restaurants before their visit.

Question five: The most common comment and reviews that attracts the respondents to choose their local restaurant

Table (5): the most common comment and reviews that attracts the respondents to choose a restaurant

\begin{tabular}{|c|c|c|c|c|c|c|c|}
\hline Most comment & Freq & $\%$ & $\begin{array}{c}\text { Restaurant } \\
\text { Region }\end{array}$ & $\begin{array}{l}\text { Mean } \\
\text { Rank } \\
\text { Score }\end{array}$ & $\begin{array}{c}\text { Std. } \\
\text { Deviation }\end{array}$ & $\begin{array}{l}\text { Chi- } \\
\text { Square }\end{array}$ & $\begin{array}{l}\text { Asymp. } \\
\text { Sig. (2- } \\
\text { tailed) }\end{array}$ \\
\hline Food quality & 52 & 38.0 & Cairo & 71.68 & \multirow[t]{5}{*}{1.580} & \multirow[t]{5}{*}{3.373} & \multirow{5}{*}{.185} \\
\hline Price & 19 & 13.9 & Alexandria & 59.43 & & & \\
\hline Restaurant atmosphere & 22 & 16.1 & \multirow[t]{3}{*}{ Mansoura } & \multirow[t]{3}{*}{73.87} & & & \\
\hline Restaurant Hygiene & 15 & 10.9 & & & & & \\
\hline Staff Attitude & 29 & 21.2 & & & & & \\
\hline
\end{tabular}

The findings (Table 5) indicate that food quality was the most effective comment on the respondents'

\begin{tabular}{|c|c|c|c|c|c|c|c|c|}
\hline \multirow[b]{2}{*}{ major components } & \multicolumn{5}{|c|}{ Importance levels } & \multirow[t]{2}{*}{ Total } & \multirow{2}{*}{$\begin{array}{c}\text { Weighted } \\
\text { average } \\
\%\end{array}$} & \multirow[t]{2}{*}{ Ranking } \\
\hline & $\begin{array}{c}1 \\
\text { The } \\
\text { least }\end{array}$ & 2 & 3 & 4 & $\begin{array}{c}5 \\
\text { The } \\
\text { most }\end{array}$ & & & \\
\hline Dish photo & 63 & 39 & 14 & 11 & 10 & 277 & 40.4 & 5 \\
\hline $\begin{array}{l}\text { Status of friends and relative } \\
\text { concerning visiting the restaurant }\end{array}$ & 4 & 20 & 41 & 46 & 26 & 481 & 70.2 & 2 \\
\hline Guest comments and reviews & 14 & 15 & 20 & 29 & 59 & 515 & 75.2 & 1 \\
\hline $\begin{array}{l}\text { Photos of celebrities who visited } \\
\text { the restaurant }\end{array}$ & 12 & 19 & 31 & 45 & 30 & 473 & 69 & 3 \\
\hline $\begin{array}{lll}\begin{array}{l}\text { Videos } \\
\text { operation }\end{array} & \text { regarding } & \text { restaurant } \\
\end{array}$ & 44 & 44 & 31 & 6 & 12 & 309 & 45.1 & 4 \\
\hline
\end{tabular}

preferences with an average percent of 38; staff attitude was the second concern of the respondents with an average percent of 21.2; restaurant atmosphere was the third (16.15). Moreover, commenting about price was less effective $(13.9 \%)$, while restaurant hygiene was the least $(10.9 \%)$ This means that food quality and staff attitude are the main factors for most people, Furthermore, the findings assure that there wasn't a significant difference among the findings of the three regions.

Question Six: Ranking the major components that attract the respondents to visit local restaurants regarding social media pages

Table 6: Ranking the major components that attract customers to visit the restaurant regarding social media pages

The results (Table 6) indicate that "guest comments and reviews" were the most important issue that attracts the customers to visit new local restaurants $(75.2 \%)$, also "status of friends and relatives concerning their visit" was 
in the second order of importance $(70.2 \%)$. Again, "photos of celebrities who visited the restaurant" came in the third order $(69 \%)$. Finally, "videos regarding restaurant operation" and "dish photos" came the last $(45.1 \%$ and $40.4 \%$ respectively). These findings consent with Garcia (2011) who indicated that the social recommendations and reviews measure the impact of online conversation on the sites and produce valuable feedback for all participants.

\section{Question seven: Customer perception concerning using social media as a marketing tool in local restaurants}

Table (7): Customer perception concerning using social media as a marketing tool in local restaurants

\begin{tabular}{|c|c|c|c|c|c|c|}
\hline \multirow[t]{2}{*}{ Social media attributes } & \multicolumn{2}{|c|}{ Agree } & \multicolumn{2}{|c|}{$\begin{array}{l}\text { Neither Agree } \\
\text { nor Disagree }\end{array}$} & \multicolumn{2}{|c|}{ Disagree } \\
\hline & Freq & $\%$ & Freq & $\%$ & Freq & $\%$ \\
\hline $\begin{array}{l}\text { 1- Positive and negative reviews can change customers } \\
\text { perception about the restaurant }\end{array}$ & 98 & 71.5 & 11 & 8 & 28 & 20.5 \\
\hline $\begin{array}{l}\text { 2- The customers buy the product or service according to } \\
\text { information on social media }\end{array}$ & 87 & 63.5 & 9 & 6.6 & 41 & 29.9 \\
\hline $\begin{array}{l}\text { 3- The customers trust the community of social media } \\
\text { regarding the accuracy of the information provided to the } \\
\text { public }\end{array}$ & 79 & 57.7 & 37 & 27 & 21 & 15.3 \\
\hline $\begin{array}{l}\text { 4-Social media pages help the customers to reach the } \\
\text { local restaurant and update you with news }\end{array}$ & 103 & 75.2 & 10 & 7.3 & 24 & 17.5 \\
\hline $\begin{array}{l}\text { 5- Social media marketing is better than traditional } \\
\text { marketing, e.g. newspaper, TV }\end{array}$ & 91 & 66.4 & 11 & 8 & 35 & 25.6 \\
\hline $\begin{array}{l}\text { 6- Social media can make the customers be highly loyal to } \\
\text { the local restaurant }\end{array}$ & 88 & 64.3 & 7 & 5.1 & 42 & 30.7 \\
\hline
\end{tabular}

The findings (Table 7) indicate that the majority of the respondents agree that "positive and negative reviews can change the customers' perception about the restaurant" with an average percent of (71.5). These findings concur also with Cheung and Thadani (2012) who indicated that customers are much more influenced by negative and positive reviews which help them to decide. Also (63.5\%) of the respondents agree that "they buy the product or service according to information through social media".

According to the respondents' opinions about "trusting the community of social media", the weighted percent in the three investigated regions was (57.7). These findings agree with Dabwan (2014) who mentioned that most customers trust restaurants review posted on social media, while $75.2 \%$ of the respondents agree that "social media pages help them to reach the local restaurant and update their knowledge". These findings confirm those of Grizane and Jurgelane (2016) who indicated that the social media is a tool which allows customers to place and perceive different type information which requires constant updating to attract customers. Moreover, $66.4 \%$ of the sample agree that "social media as a marketing tool is better than traditional marketing". These findings agree with Timilsina (2017) who confirmed that the majority of customers strongly agree that social media is better than traditional marketing. Again, $64.3 \%$ of the respondents agree that "social media can make them highly loyal to their local restaurants". This result confirms the previous findings reported by Brodie et al.(2009) who stated that social media can help to communicate with loyal customers and improve the perceptions of people toward offered products or services, then share information and learn better about the customers.

\section{Demographic Characteristics}

Table (8): Demographic characteristics

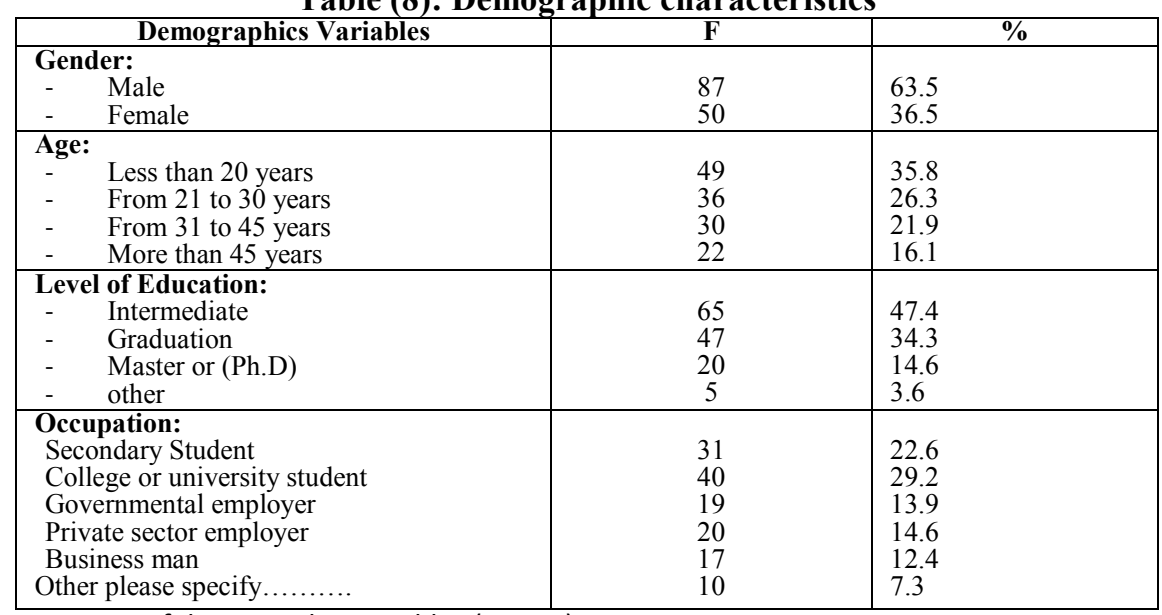

Frequency and percentage of demographic variables $(\mathrm{N}=137)$.

Table (8) illustrates that $63.5 \%$ of the local restaurant visitors were male, while $36.5 \%$ were female. Concerning local restaurant visitors age, the findings show that most of local restaurants' customers were below 40 years. The results also showed that local restaurant customers have different qualifications. In other words, the level of education doesn't affect buying decisions in those restaurants. Finally, the findings illustrate that secondary and university students prefer this type of restaurants, this is coinciding with the age below 40 years of local restaurant visitors. 
Comparison among the three regions in terms of social media attributes

The Kruskal-Wallis $\mathrm{H}$ test was used to compare customers' perceptions among the three regions in order to determine if there is a significant difference among them in terms of social media attributes. The following table (9) presents this issue.

Table 9: A summary of the Kruskal-Wallis $H$ test among the regions in terms of social media attributes

\begin{tabular}{|c|c|c|c|c|c|}
\hline Attributes & Regions & $\begin{array}{l}\text { Mean } \\
\text { rank } \\
\text { score }\end{array}$ & $\begin{array}{c}\text { Std. } \\
\text { Deviation }\end{array}$ & $\begin{array}{l}\text { Chi- } \\
\text { Square }\end{array}$ & $\begin{array}{l}\text { Asymp. } \\
\text { Sig. }\end{array}$ \\
\hline \multirow{3}{*}{$\begin{array}{l}\text { 1- Positive and negative reviews can change } \\
\text { customers' perception about the restaurant }\end{array}$} & Cairo & 68.44 & \multirow[t]{3}{*}{.48838} & \multirow[t]{3}{*}{3.652} & \multirow[t]{3}{*}{.161} \\
\hline & Alexandria & 63.96 & & & \\
\hline & Mansoura & 73.92 & & & \\
\hline \multirow{3}{*}{$\begin{array}{l}\text { 2- The customer buys the product or service } \\
\text { according to information through social media }\end{array}$} & Cairo & 124.82 & \multirow[t]{3}{*}{.45196} & \multirow[t]{3}{*}{1.719} & \multirow[t]{3}{*}{.423} \\
\hline & Alexandria & 187.70 & & & \\
\hline & Mansoura & 191.01 & & & \\
\hline \multirow{3}{*}{$\begin{array}{l}\text { 3- the customers trust the community of social } \\
\text { media regarding the accuracy of the information } \\
\text { provided to the public }\end{array}$} & Cairo & 164.55 & \multirow[t]{3}{*}{.68607} & \multirow[t]{3}{*}{2.323} & \multirow[t]{3}{*}{.313} \\
\hline & Alexandria & 181.77 & & & \\
\hline & Mansoura & 179.23 & & & \\
\hline \multirow{3}{*}{$\begin{array}{l}\text { 4-Social media pages help customers to reach the } \\
\text { local restaurant and update them with news }\end{array}$} & Cairo & 139.16 & \multirow[t]{3}{*}{.36951} & \multirow[t]{3}{*}{2.338} & \multirow[t]{3}{*}{.311} \\
\hline & Alexandria & 184.25 & & & \\
\hline & Mansoura & 206.49 & & & \\
\hline \multirow{3}{*}{$\begin{array}{l}\text { 5- Social media marketing is better than traditional } \\
\text { marketing, e.g. newspaper, TV }\end{array}$} & Cairo & 129.80 & \multirow[t]{3}{*}{.58333} & \multirow[t]{3}{*}{7.637} & \multirow[t]{3}{*}{.022} \\
\hline & Alexandria & 168.24 & & & \\
\hline & Mansoura & 191.23 & & & \\
\hline \multirow{3}{*}{$\begin{array}{l}\text { 6- Social media can make the customers be highly } \\
\text { loyal to the local restaurant }\end{array}$} & Cairo & 170.31 & \multirow[t]{3}{*}{.74575} & \multirow[t]{3}{*}{.657} & \multirow[t]{3}{*}{.720} \\
\hline & Alexandria & 182.00 & & & \\
\hline & Mansoura & 179.33 & & & \\
\hline
\end{tabular}

P-value $<0.05=$ Significant

As shown in Table 9, the Kruskal-Wallis H test revealed no significant difference among the regions in terms of social media attributes.

Firstly, Mansoura showed the highest mean score $(M=73.92)$; followed by Cairo $(M=68.44)$; then Alexandria $(\mathrm{M}=63.96)$. This means that positive and negative reviews can change customers' perception of the restaurants of Mansoura region that ranked first. Secondly, Mansoura showed the highest mean score $(\mathrm{M}=191.01)$; followed by Alexandria $(M=187.70)$; then Cairo $(M=124.82)$ regarding buying the product or service according to information through social media.

Thirdly, with reference to the customers who trust the community of social media regarding the accuracy of information provided to the public, Alexandria achieved the highest mean score $(\mathrm{M}=181.77)$. Fourthly, regarding social media pages that help you to reach for local restaurants and update you with news, Mansoura achieved the highest mean score $(\mathrm{M}=206.49)$.

Fifthly, in terms of to know whether social media marketing is better than traditional marketing, e.g. newspaper, TV, Mansoura achieved the highest mean score $(\mathrm{M}=191.23)$. This means that customers in Mansoura prefer social media marketing than traditional marketing. Finally, regarding "social media can make the customer highly loyal to the local restaurant", Alexandria achieved the highest mean score $(\mathrm{M}=182.00)$.

\section{Analysis of Interviews with Restaurants Managers}

1- Restaurants have pages on social media to communicate with their customers

All managers in the investigated restaurants mentioned that their restaurants' pages on various social networking sites such as Facebook and Instagram communicate with their customers. Moreover, twelve managers added that the presence of social media has become a necessity to success and not optional. Also, four managers stated that social networking sites have become a strong supporter of restaurants, and therefore, the presence of any restaurant on the various social media is considered a factor of success. These findings are supported by four of the interviewees who stated that:

Nowadays, all people have accounts on the social networking sites. Therefore, our presence on these sites is considered vital to communicate with our customers to know how to evaluate us if we are negative or positive.

2- Which is better: social media marketing or traditional marketing (e.g. TV- newspaper - magazines)?

All managers agree that social media as a marketing tool is better than traditional marketing (e.g. TVnewspaper - magazines- outdoor advertising). Hence, they use the former rather than the latter. Moreover, most managers clarify that their preferences of social media is because it is far less expensive. Furthermore, some of managers state that they prefer social media because most customers interact more with them through social network sites. On the other hand, five managers mentioned that traditional marketing is very important in inaugurating new restaurants by using flyers and brochures. These findings are supported by five of the interviewees who stated that:

Traditional marketing is important but social networking pages are recently the most important and powerful marketing tools as they are able to communicate with the customer during the whole day, unlike the traditional marketing, which aims to deliver a message only without assessing the customer's opinion.

\section{3- The sites, applications and pages of social media used by restaurants to deal with customers}

All managers stated that they have pages on Facebook and they display all the restaurant's news on it. Moreover, fourteen managers added that they have a page on Instagram through which the restaurant uploads pictures of the restaurant and the menus offered. Furthermore, six managers stated that they use Whatsapp 
application to communicate with customers by means of telephone numbers, give the customer new offers and to receive complaints and suggestions. These findings are supported by three of the interviewees who stated that: Facebook, Instagram and whatsapp have become widely known and have many users. Facebook and instagram display many pictures regarding restaurant needed by the customers and we can download pictures of the restaurant, chairs, tables and menus, and the customer can see the restaurant even if he does not come and the presentation of these pictures motivate the customer to visit the restaurant.

\section{4- Time period of updating restaurant pages on social media}

Six managers stated that they update their pages on social media when the restaurant changes its menus or adds new items. Four managers added that they make updating to show new pictures of the dishes in the menus or to add pictures of celebrities who visited the restaurant. Furthermore, three managers stated that they make updating on social media pages when they make renovations and they want to tell customers about any changes regarding restaurant operation. On the other hand, three managers stated that they update their pages frequently every day by sharing updated news about the restaurant so as to make customers feel the existence of the restaurant and not forget it. Moreover, two managers added that continuous updating is very important, for example, greeting customers on different occasions such as feasts or to invite customers to watch important matches. These findings are supported by two of the interviewees who stated that:

Continuous updating of the page gives the customer a distinct impression that we are always working to achieve quality and to satisfy them.

\section{5- Benefits of using social media}

Eight managers stated that one of the main benefits of using social media is to target a large number of customers, because most of customers have pages on social media. Moreover, four mangers added that one of the main benefits of using social media is that it is less expensive than traditional marketing. Furthermore, three managers stated that they communicate with customers easily. Furthermore, three managers mentioned that social media attracts new customers to restaurant. Another benefit is sharing photos in social media pages regarding the restaurant. These findings are supported by five of the interviewees who stated that:

If we compare between the amount of our profits before and after using the social networking pages, we will find that our profits increased after we had used social networking page and many customers know us via Facebook.

\section{6- Method of managing social media pages}

Eleven managers stated that they manage pages on social media by digital marketing agencies. These agencies are responsible for responding to customers and increasing the number of followers on the page to reach as many people as possible. On the other hand, seven managers mentioned that they manage pages on social media by themselves and thus they allocate one of the management to be responsible for the restaurant pages. These findings are supported by four of the interviewees who stated that:

Digital marketing agencies play a very important role in the success of any restaurant, such as targeting a specific age range suitable for the type of restaurant and responding to the customers' comments within 24 hours. One of the most important roles of digital marketing agencies is taking shoots of high-quality videos for every period in the restaurant and for the celebrities who visited the restaurant, publishing it on my page on Facebook

\section{7- The impact of social media on restaurant operations}

Six managers reported that the most important impact of social media on restaurant operations is increasing profits clearly. Furthermore, five managers added that another impact is increasing proliferation and fame of the restaurant. Four managers stated that social networking pages enable customers to get the address and phone number of the restaurant in case they lost the restaurant's flyers or brochures. Three managers added that improving menu items on social networking pages gives customers the advantage of being familiar with the menu and gives us the advantage of saving time and effort in restaurant operations when customers call or come to know the menu items. These findings are supported by two of the interviewees who commented that:

When customers call restaurants, they want to get some information regarding menu items, this will cost us more time. On the other hand, when customers follow us on networking pages such as Facebook and Instagram, customers are aware of the menu, and, therefore, the time spent in the call is less, so the call will be shorter and we can receive other calls.

\section{8- The importance of using social media pages by local restaurants}

Six managers stated that social media pages target particular online groups for limited time deals and this certainly increases the importance of using social media especially at times of recession. Five managers illustrated that the customer may be embarrassed to show his comment to management but his comment will be more visible and clear on social networking pages without embarrassment which leads to that the restaurants can improve service quality, and customer satisfaction and then product recommendation. Four managers referred to the existence of restaurants on pages of social media which are characterized by large numbers of followers specialized in restaurants sector. Even if a restaurant has good reviews on these pages, then the customer will come to visit it and this leads to high productivity. Two managers mentioned that creating a special event on restaurant page has a big importance to local restaurant performance which can attract new customers and increase productivity. One manager illustrated that social networking pages help the restaurant to transform customer satisfaction into customer loyalty. These findings are supported by one of the interviewees who stated that:

Using of social media in some restaurants increases their productivity and profitability by creating a special event for their customers on the restaurant's page on Facebook.

\section{9- Restaurants deal with customers' comments and reviews whether they are positive or negative}

All managers reported that when they receive any negative comments or reviews, they communicate with customers directly by sending them a private message to their own message box or through telephone number, and, then the restaurant identifies the service failure regarding the type of complaint, timing of the complaint and the best solution for solving it in different ways. All managers added that when they receive positive comments, they thank customers and the positive comments are used to develop service quality. Most managers added that many positive, as well as negative, reviews can change customers 'perception of the restaurant brand. Some 
managers added that reviews of customers' families and friends help customers in choosing any restaurant they want to eat in. These findings are supported by three of the interviewees who stated that:

Customers' negative comments and not solving a problem as such on social networking pages can be the reasons for ending a restaurant's march. Therefore, we try to solve the service failure because some competitors could exploit the bad comments and reviews against us.

\section{0- The problems facing the restaurant management while dealing with social media}

Ten managers stated that some competitors pretend to be customers to write negative comments about restaurants in order to make the customer refuse to visit their restaurant. This is one of the main problems that face the restaurant management while dealing with social media. Four managers illustrated that the main problems are represented by rumors and blackmail which are among the most negative characteristics of social networking pages. Unfortunately, it affects restaurants strongly and their impact is evident on the lack of revenue. Three managers added that other problems facing them are represented in hacking our accounts on social networking pages. Unfortunately this is one of the worst problems because when their pages are hacked, they lose control and the hacker becomes the controller and can load any data. One manager mentioned that one of the common flaws of social networking pages is that some people may write bad comments about them without visiting their restaurants and this is a fatal flaw. These findings are supported by three of the interviewees who stated that:

Unfortunately, our restaurants were exposed to fierce rumors, that affected us negatively very much and we could not stop it because the customer believes the social networking pages without checking.

Based on the above discussion suggested is a model reflecting the most important results obtained from customers and managers regarding the use of social media in local restaurants (see the figure).

Figure: A suggested practice model for restaurants managers for improving service quality regarding using social media and its value to local restaurants in Egypt

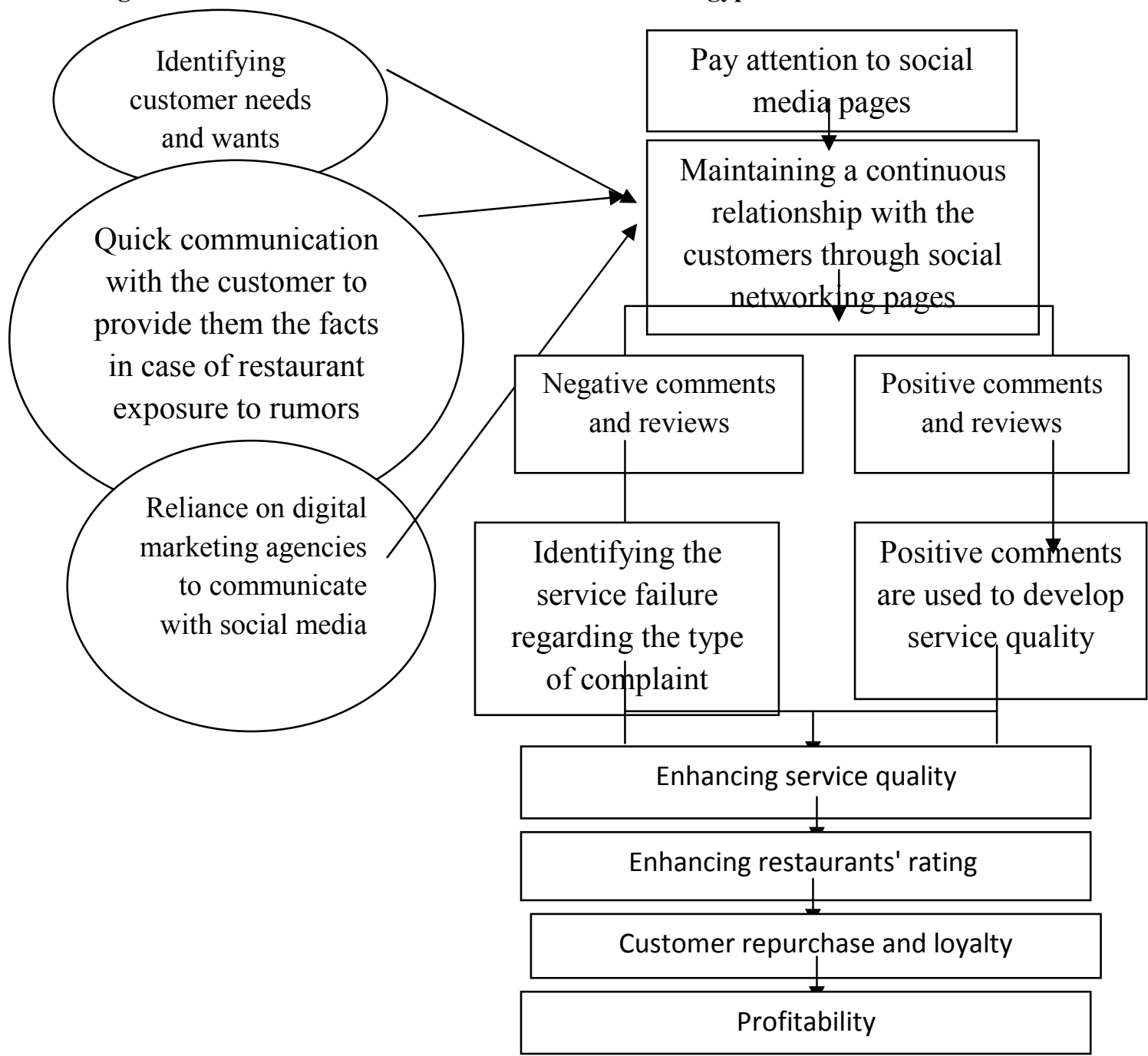

Limitations and Future Study

The current study has two limitations. First, this study may not be comprehensive enough to represent all types of restaurants. The local restaurants were chosen. Future research may include comparing the effect of social media pages on restaurants chain and local restaurants to provide more meaningful results. Second the present study measures the effective of using social media pages on local Restaurants' productivity in three regions: Cairo, Alexandria and Mansoura. The majority of restaurant data were obtained from face to face interview. Future hospitality research is needed to strengthen the theoretical and empirical background that interpret the role of social media pages on domestic tourism 


\section{Conclusion}

Now internet in general and social media in particular has become a necessity in our life as well as business. Hence, a lot of industries use social networking sites to interact and transmit information with their consumers. One of these fields is local restaurant. So, social media help these restaurants to maintain a good customer relationship, to enhance its image, improve productivity and thus increase their revenues. The study's results illustrated that most of the local restaurant customers use social media for getting further information on their restaurants. All managers in the selected restaurants indicated that they use social media nowadays as a marketing tool especially Facebook which became more popular and usable by two sides (restaurant and customers), some of the investigated restaurants manage their sites and pages through digital marketing agencies (to gain better results) and others manage their pages by themselves. The study also assured that social media is an effective tool used by local restaurants to send messages and regular news letters to their customers containing the newest information regarding new products and any promotion or event to promote and give awareness to consumer about the restaurant news and thus can increase restaurant productivity. Furthermore, the study findings also indicated that social media also helpful in the long term as customers can establish more and more trust and perceive value on restaurant productivity and image.

\section{References}

- Akhundzada, D. (2016). "How Social Media Has Changed Marketing Strategies of Hospitality Businesses in Prague". Unpublished Bachelor of Science In Business Administration, State University of New York Empire State Collage, pp.2333

- Barker, M.; Barker, D.; Bormann, N.; Roberts, M. and Zahay, D. (2016). "Social media marketing: a strategic approach. Second edition. Boston, MA: Cengage Learning". available from, https://oamk.finna.fi/Record/kajakki.51069 [Accessed 21 March 2017]

- Billingsley, C., (2017). "5 ways brands respond to negative socialmediacomments". available from: http://www.seeksocialmedia.com/respond-negative-social-media-comments/ [Accessed 09February.2017].

- Brodie, R.; Juric, B. and Hollebeek, L. (2009). "Consumer engagement in a virtual brand community: An exploratory analysis", Journal of Business Research., vol. 66, pp.105-114.

- Brooks, G. (2009). "Writing a new page in the online book", Media and Marketing Magazine, pp.13-14

- Bulearca M. and Bulearca, S. (2010). "Twitter: A viable marketing tool for SMEs," Journal of Global Business and Management Research, vol. 2, no. 4, pp. 296-309.

- Cheung, C. and Thadani, D. (2012). The impact of electronic word-of-mouth communication: A literature analysis and integrative model. Decision Support Systems, 54(1), pp.461-470.

- Dabwan, N. (2014) "The Impact of Social Media in order to promote the Restaurants businesses in Jeddah, Unpublished Bachelor in entrepreneurship, Effat University, pp.1-20

- Garcia, I. (2011). "Social Media-Integration-Theory-Model". [online]. Available from: http://www.socialmediatoday.com/content/social-media-integration-theory-model [Accessed 28 February. 2017 ].

- Gelb, B.D. and Sundaram, S. (2002). "Adapting to word of mouse". Bus. Hor. 45 (4), 21-25

- Grizane,T. and Jurgelane, I. (2016). "Social Media Impact on Business Evaluation”. Computer Science 104 190-196. Available from: http://www.sciencedirect.com/science/article/pii/S18770509173010[Accessed 07 August. 2017].

- Kaplan, A. and Haenlein, M. (2009). "The fairyland of Second Life: Virtual social worldsand how to use them". Business Horizons, 52(6), 563-572.

- Kasavana, L. (2008). "Hospitality marketing: “A retrospective analysis (1960-2010) and predictions (2010-2020)". Cornell Hospitality Quarterly 51 (4): 459-69.

- Kennedy, A. (2006). "Electronic customer relationship management (eCRM): Opportunities and challenges in a digital world. Irish Marketing Review", 18(1,2), pp.58-68

- Kucukemiroglu, S. and Kara, A. (2015). "Online word-of-mouth communication on social networking sites". International Journal of Commerce and Management, 25(1).

- Maines, M. (2009).“Where in the world is Kogi Korean BBQ”? Inc.com. available from: "http://inc.com/news/articles/" http://inc.com/news/articles/ (accessed July14, 2017).

- Mangold, W. and Faulds, D. (2009). "Social media: The new hybrid element of the promotion mix". Business Horizons 52 (4): 357-65.

- Needles, A. and Thompson, G., (2013). "Social media use in the restaurant industry: a work in progress". Cornell Hospitality Rep. $13(7), 6-17$

- Oxforddictionaries.com, (2015). "Social network - definition of social network in English from the Oxford dictionary". [online]. Available from: http://www.oxforddictionaries.com/definition/english/social-network [Accessed 19 Mar.2017].

- Severi, E.; Ling, K. and Nasermoadeli, A., (2014). "The impacts of electronic word of mouth on brand equity in the context of social media," International Journal of Business and Management, vol. 9, no. 8, pp. 84-96,

- Soewandi, M. (2015). "The impact of social media communication forms on brand equity dimensions and consumer purchase intention," iBuss Management, vol. 3, no. 2, pp. 204-213.

- Timilsina, M. (2017). "Impacts of social media in restaurant businesses -A case study of restaurants based on Oulu region", Bachelor's Thesis, available from: "https://www.theseus.fi/bitstream/handle/10024/128861/TimilsinaManoj.pdf?sequence" [Accessed 15 December2016].

- Walter, E. (2012). "The Rise of Visual Social Media". available from: "http://www.fastcompany.com/3000794/rise-visualsocial-media"

- Windels, J. (2012). "How social media is revolutionising the restaurant industry". [online] Brandwatch. Available from: "https://www.brandwatch.com/2012/02/socialmediaintherestaurant-industry/" [Accessed 08 April. 2017].

- Wyrwoll, C. (2014). "Social Media: Fundamentals, Models, and Ranking of User-Generated Content. 1st ed. [ebook] Wiesbaden: Springer Fachmedien Wiesbaden". Available from: http://link.springer.com/book/10.1007\%2F978-3-658-069841 [Accessed 19 March 2017].

- Young, L. (2010). "Brave new world. Foodservice and Hospitality". 42 (11): 24-28. 


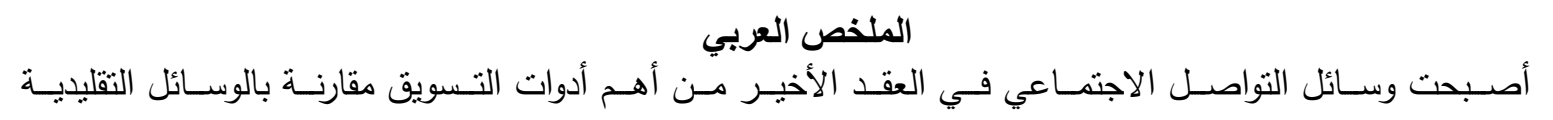

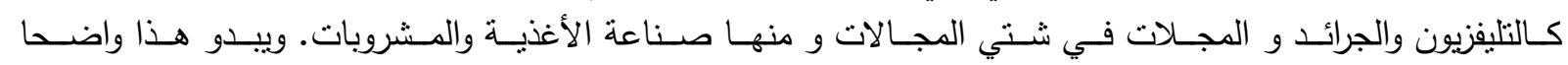

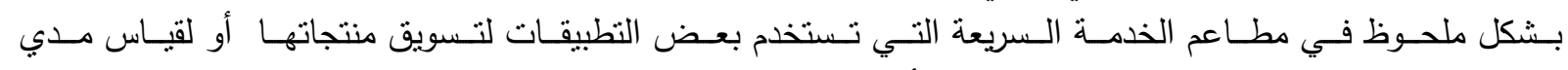

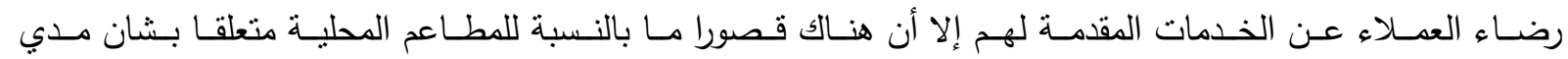

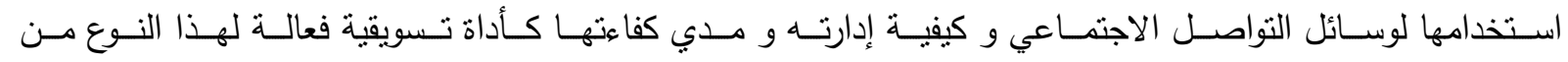

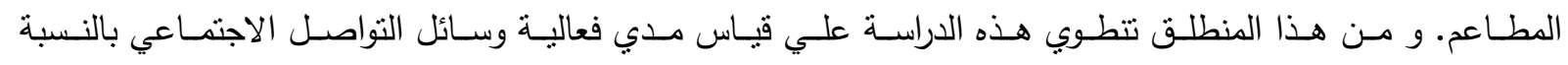

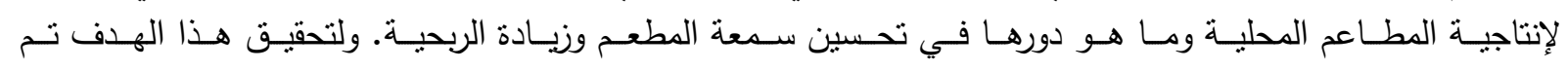

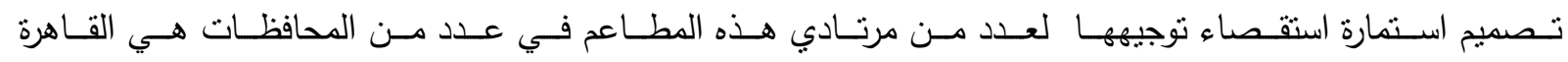

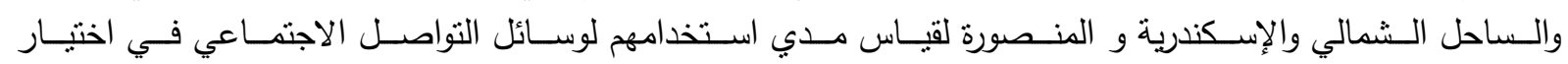

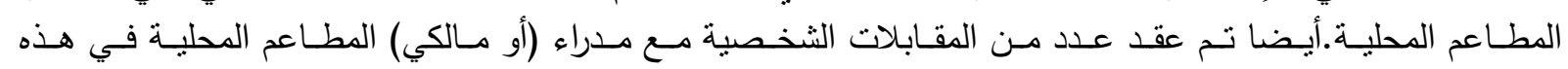

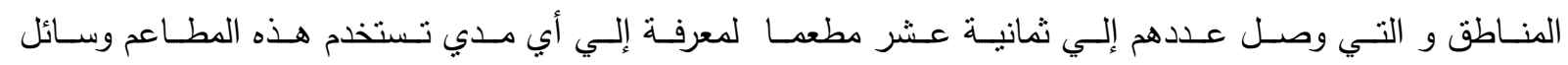

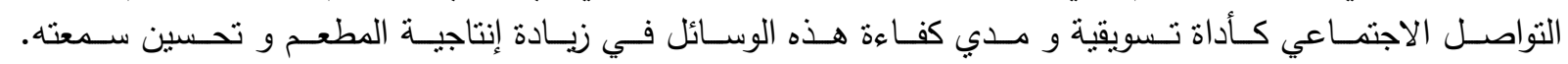

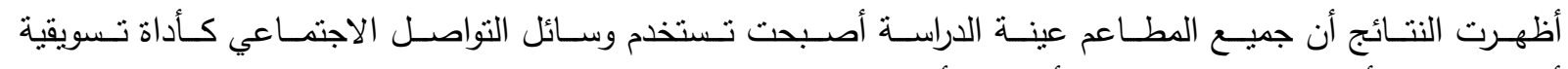

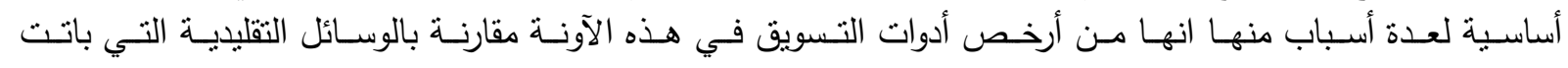

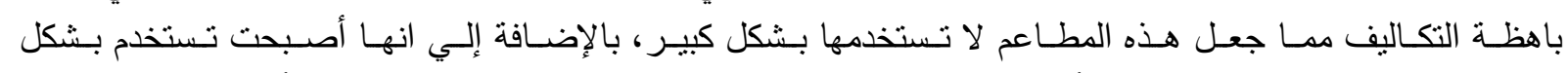

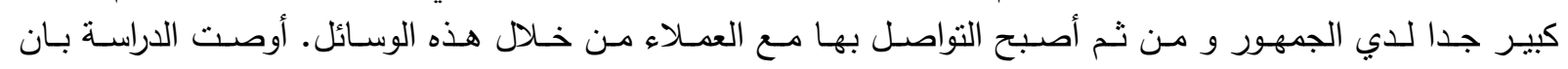

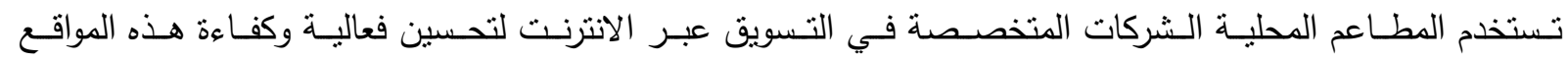

